Document downloaded from:

http://hdl.handle.net/10251/51129

This paper must be cited as:

Alcázar Ortega, M.; Ảlvarez Bel, CM.; Domijan, A.; Escrivá Escrivá, G. (2012). Economic and environmental evaluation of customers' flexibility participating in operation markets: Application to the meat industry. Energy. 41(1):368-379. doi:10.1016/j.energy.2012.03.003.

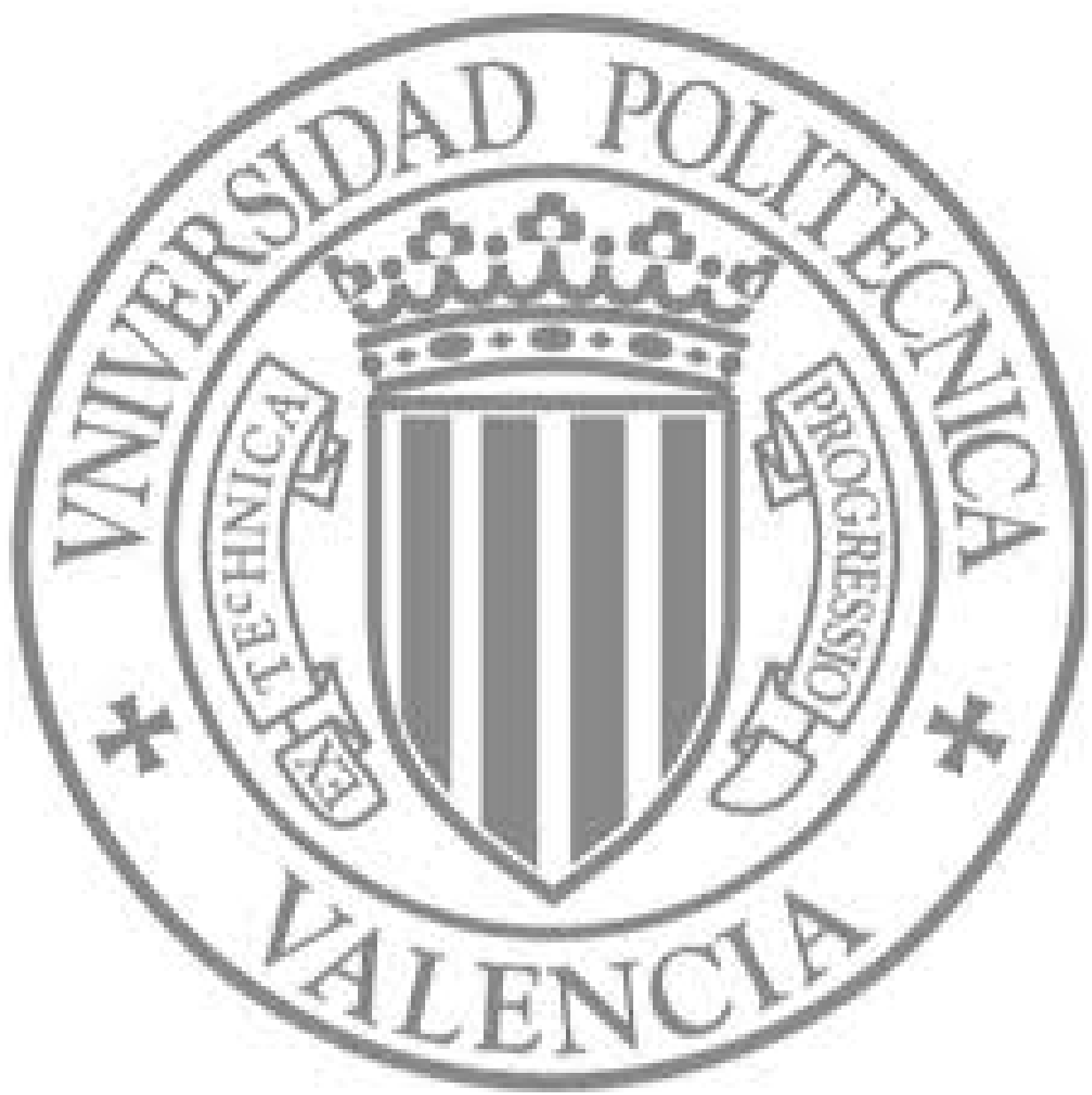

The final publication is available at

http://dx.doi.org/10.1016/j.energy.2012.03.003

Copyright Elsevier 


\title{
ECONOMIC AND ENVIRONMENTAL EVALUATION OF \\ CUSTOMERS' FLEXIBILITY PARTICIPATING IN OPERATION \\ MARKETS: APPLICATION TO THE MEAT INDUSTRY
}

\author{
Manuel Alcázar-Ortega $\left({ }^{*}\right)\left({ }^{a}\right)$, Carlos Álvarez-Bel $\left({ }^{a}\right)$, Alexander Domijan $\left({ }^{b}\right)$, \\ Guillermo Escrivá-Escrivá( $\left({ }^{\mathrm{a}}\right)$
}

$\left({ }^{a}\right)$ Universidad Politécnica de Valencia, Institute for Energy Engineering Camino de Vera, s/n, edificio 8E, escalera F, 5ª planta. 46022 Valencia (SPAIN) (e-mail: malcazar@iie.upv.es)

$\left({ }^{b}\right)$ University at Buffalo, Power Center for Utility Explorations

332 Bonner Hall, Buffalo, NY 14260-2050, USA

(e-mail: adomijan@buffalo.edu)

\section{Abstract}

This paper presents a methodology, which is applied to the meat industry, for the evaluation and assessment of the economical impact of customers participating in operation markets by using the flexibility they may have, as well as the amount of $\mathrm{CO}_{2}$ avoided to be emitted into the atmosphere.

The particular market conditions in the Spanish context have been considered. Thus, real prices of operation markets in Spain have been used to evaluate the potential profitability, even if customers are not actually allowed to participate in such markets at the moment.

\footnotetext{
Corresponding Author: Manuel Alcázar-Ortega. Institute for Energy Engineering. Universidad Politécnica de Valencia. Camino de Vera, s/n, edificio 8E, escalera F, 5 $5^{\text {a }}$ planta, 46022 Valencia (SPAIN). Tel. +34 963877271 Fax: +34 963877272 email: malcazar@iie.upv.es
} 
The economic evaluation requires a cost-benefit analysis, as presented in the methodology. The procedure followed evaluates the maximum daily benefit obtained by the customer when offering all its flexibility in operation markets, so that it can make a decision based on the expected benefits. In order to determine the value of this benefit, different aspects are evaluated, including the amount of money saved during the flexibility actions due to the energy not consumed or shifted to cheaper periods, as well as the costs that the customer incurs when a flexibility action is performed. Finally, the obtained results for a typical customer are extrapolated to the whole segment in the country

Keywords: Food Industry, Load Management, Power Control, Power Demand, Production Management.

\section{Introduction}

Active customer participation is essential for the proper development of electricity systems as no electricity market is complete without the active participation of the final consumer [1], [2] . Consequently, the adequate means of guaranteeing effective competition in electricity markets needs to be enhanced, including demand response (DR) programs which allow customers to participate in such markets [3].

Operating power systems securely is the highest priority for system operators because the degradation of operation conditions in any part of the system can produce instabilities system-wide [4]. For that reason, generators are usually the ones allowed to provide operators with the different services required for the proper operation of power systems. However, regulations in some countries allow the demand to participate in different operation markets if they can provide services by managing their loads while also fulfilling the requirements of power reliability and time of response [5], [6]. Indeed, as demonstrated in previous research [5], [7], customers are technically able to participate in operation markets and to reduce their loads quickly and reliably. Moreover, modern information and communication technologies are providing customers with the capability of implementing automatic control [8], [9], making information more accessible since electricity prices 
and similar data can be automatically transferred to customers that may react to such signals. Yet, participation is not significant enough according to the full and currently underused potential [10]. One of the main reasons is that customers are not aware about the real potential they have, together with their low practical knowledge about the functioning of electricity markets [11]. This is particularly true at the domestic level, where consumers have little knowledge of billing systems, although the participation of industrial and commercial customers is continually evolving [12].

Different experiences developed by other researchers [13], [14], [15], [16] demonstrate that the active participation of the customer in energy and operation markets may help to improve the performance of electricity systems. However, no examples of previous research were found that described how to determine potential customer flexibility in order to take advantage of different prices of electricity throughout time. This is especially true when such actions are applied to sensitive processes directly related to the quality of the final product, which tend to make customers wary of changing any element or parameter of those processes. This fact has traditionally made customers reticent to change any element or parameter of those processes. Thus, the underlying aim of this paper is to make some progress in this area. In particular, a methodology to evaluate and assess the economic impact of customers participating in operation markets by using their flexibility, as well as the amount of $\mathrm{CO}_{2}$ emissions that are avoided, is presented.

The paper is organized as follows: an overview about the electricity market in Spain is presented in Section 2 as it is the framework where the methodology has been applied and validated. Section 3 presents the proposed methodology for the evaluation and assessment of the economic impact of customers participating in operation markets by using their flexibility, as well as the procedure to assess the carbon footprint. The methodology is applied to the meat industry sector in Section 4, where the benefits to be obtained by customers participating in such operation markets as balancing markets and secondary regulation in Spain are evaluated, as well as the impact that the participation of the whole segment may have in the power system. Finally, some conclusions are stated in section 5 . 


\section{Electricity market overview in Spain}

Spain belongs to the Iberian Electricity Market (MIBEL), which is common for Spain and Portugal. Created in 2001, MIBEL is composed of different organized and non-organized markets where electricity and related financial instruments are traded. About 29 million customers, consuming 300 TWh annually, participate in this market [17].

MIBEL can be divided into organized and non-organized markets. Organized markets include:

- The forward market, where continuous operation or auctions are used and which allows physical or financial settlements. This market is managed by OMIP (the Portuguese pole), which controls, oversees and compensates the forward market.

- Spot market, managed by OMEL (the Spanish pole) where two time horizons are considered:

- Daily market, if energy packages for the day following the contract are traded.

- Intra-daily market, if traded packages of energy are delivered within less than 24 hours.

- Operation markets. These are managed individually in Portugal and Spain by the respective TSOs. Operation markets in Spain are introduced in section 2.1.

Non-organized markets (over-the-counter trading, OTC) are based on bilateral contracts between any of the participants in the market. OTC trading is commonly used by large customers and energy traders which directly negotiate large amount of energy packages with power plants before the day ahead.

Most energy is traded in organized markets, and the Spot market is preferred by lberian customers, as shown in Figure 1 for the year 2009. Two-thirds of Iberian customers trade electricity in organized markets, while bilateral contracts are preferred by only a third of participants. Among the different options available in organized markets, forward markets are used by just $6 \%$ of customers, whereas $59 \%$ of customers in Spain and Portugal use the Spot market.

Customers can purchase their electricity supply in the deregulated market by participating in organized or non-organized markets. However, small customers who contract less than $10 \mathrm{~kW}$ can take advantage of a regulated tariff. 
Depending on the specific contract of the customer, different periods could be applied, ranging from a single period (flat contract) for customers with less than $10 \mathrm{~kW}$ of contracted power, to six periods for customers contracting more than $450 \mathrm{~kW}$. As an example, Table 1 shows the different periods considered for a seasonality contract.

\subsection{Operation markets in Spain}

The Spanish Transmission System Operator (TSO), Red Eléctrica de España (REE), manages the technical and economic aspects of operation markets in Spain, which include:

- Solution of technical restrictions. This is aimed at solving any incidents in the generationtransmission system that could affect the safety, quality or reliability or the power system.

- Ancillary services. These include such services as primary, secondary and tertiary regulation or voltage control, and are focused on guaranteeing the proper power supply to customers in reliable and safe conditions.

- Balancing markets. Their objective is to reconcile the deviation between demand and generation that could appear after the closing of the pool and until the beginning of the next pool market session.

Spanish customers are not allowed to participate in operation markets, unlike customers in other countries. Only very large customers (with a reducible power larger than $5 \mathrm{MW}$ ) can participate in the interruptibility program offered by REE, although the strict requirements asked of participants mean that only about 200 customers in Spain provide the system with this service. However, some recent changes, such as the creation of the Demand Side Management (DSM) department in REE or the detailed publication of different operation market results online suggest advances in this field, so a modification in the market rules to increase DR participation in the operation of the system is expected in the near term [18].

The next section evaluates the economic and environmental impact of customer participation in operation markets such as balancing markets or secondary regulation to identify the potential benefits for customers and the savings for the system. 


\section{Methodology}

The methodology developed for the economic and environmental evaluation of DR in operation markets is hereby presented. It permits the assessment of the net benefit obtained by the customer, as well as the amount of money saved by the system when not only generation resources but also DR resources are used.

\subsection{Economic evaluation}

A cost-benefit analysis is required to assess the net benefit necessary to persuade the customer to reduce its load. This begins by examining the costs that the customer incurs when managing its load. Using this data, the participation of the customer in operation markets for a whole year can be simulated to assess the profit it earns every hour.

The method used for this economic evaluation, as it is shown in Figure 2, is based on the following steps:

1. Evaluation of customer costs $C_{f}$ due to flexibility actions, considering direct and indirect costs. Direct costs comprise such concepts as control, monitoring and metering, alternative dual supply and amortizations. On the other hand, indirect costs are divided into labor costs and losses.

2. Assessment of the savings $S_{S}$ obtained by the customer due to not consuming energy during the flexibility action, taking into account the extra cost during the recovery period. This evaluation is performed based on the different prices in the electricity contract for different periods throughout the year.

3. Definition of the benefit strategy to participate or not in operation markets. Customers must quantify the benefit $B_{N E}$ they require to be willing to modify their loads, which will depend on their own market strategy. For this simulation, it has been assumed that the customer will manage its loads when the payments obtained from the system are $50 \%$ or more of the cost of the offered amount of power, according to the weighted average price in its electricity contract, and after discounting the extra costs that the customer incurs. 
4. Evaluation of the hours in which the customer may actually participate in the considered operation market. This would happen when the system operator offers a payment equal or higher than the expected benefit (as explained above).

5. Evaluation of the avoided costs for the system, determined to be the difference between the payments to the customer when managing its load and the cost of the considered operation market when only generation resources are considered.

The customer must evaluate the amount of money, $S_{S}$, saved during the flexibility action due to the energy not consumed or shifted to cheaper periods, as well as additional expenses, $C_{f}$, incurred when flexibility actions are performed. After that, it should establish the value of the benefit, $B_{N E}$, it expects in exchange for offering the service to the system. These parameters are analyzed below.

\subsubsection{Savings $\left(S_{S}\right)$}

If $p_{1}, p_{2}$ and $p_{3}$ are the prices of energy for on-peak, shoulder and valley periods, respectively, the amount of money $\left(S_{s}\right)$ saved during the flexibility action can be calculated by using the formula:

$$
S_{s}=S_{1}-\boldsymbol{\zeta}_{2}+S_{3} \bar{\gamma} \sum_{k=1}^{3} E_{1}^{k} \cdot p_{k}-\left[\sum_{k i=1}^{3} E_{2}^{k} \cdot p_{k}+\sum_{k=1}^{3} E_{3}^{k} \cdot p_{k}\right]
$$

where $S_{1}$ is the amount of money saved during the interruption, and $S_{2}$ and $S_{3}$ correspond to the extra costs generated by the consumption before and after the interruption (preparation and recovery periods). $E^{k}{ }_{1}$ is the amount of avoided energy for each "k" period of time during the interruption. Similarly, $E_{2}^{k}$ and $E_{3}^{k}$ are the amounts of additional energy consumed during the preparation and recovery time. As prices of electricity are different for each period, it is important to point out that using flexibility may afford economic savings to customers even if no energy savings are achieved.

\subsubsection{Cost of Flexibility $\left(C_{f}\right)$}

The use of flexibility may entail additional direct and/or indirect costs for customers that need to 
be evaluated. Direct costs relate to the technical capacity for carrying out a flexibility action, while indirect costs refer to those incurred as a consequence of the implementation of flexibility actions (requirement of additional manpower, loss of productivity, etc).

Direct costs comprise the following concepts:

- Cost of control $\left(C_{C}\right)$. This concept includes all actions related to the physical implementation of a flexibility-related control action, but investments to that end are not considered here (they are included in the factor $C_{A M}$ ).

- Cost of monitoring and metering $\left(C_{M M}\right)$. Monitoring and metering equipment is usually employed for other applications besides flexibility. Consequently, this cost will be shared with other involved uses.

- $\quad$ Cost of alternative dual supply $\left(C_{A S}\right)$. This cost includes fuel and technical maintenance costs when an alternative energy source is required in order to supply processes whose electricity consumption needs to be reduced. This is the case of diesel generators, accumulators or UPS batteries.

- Amortizations $\left(C_{A M}\right)$. This cost includes the annual amortization of investments required for the adaptation of facilities to implement flexibility actions. Investments comprise all the required equipment, including control, monitoring and metering devices.

Similarly, indirect costs are divided into the following groups:

- Labor cost $\left(C_{L B}\right)$. This is the additional payment that employees receive when they have to work overtime or during more expensive hours (for example nights and holidays).

- Losses $\left(C_{L S}\right)$. This cost assesses the loss of comfort or productivity. It is usually difficult to evaluate, so traditionally customers have not been allowed to perform any action that generated this cost.

The total cost $\left(C_{f}\right)$ will equal the sum of these concepts:

$C_{f}=C_{D I R E C T}+C_{I N D I R E C T}=\boldsymbol{C}_{C}+C_{M M}+C_{A S}+C_{A M} \ni \boldsymbol{C}_{L B}+C_{L S-}-(\epsilon)$

Neither the cost of energy consumed during the preparation nor during the recovery period are 
included in the above equation, since these costs have been already considered in term $S_{S}$.

The evaluation of the costs characterized above is a difficult task. However, some research has explored the field. For example, an innovative modeling tool was developed with the participation of the authors during the EU-DEEP project [19], which allows the identification, evaluation and assessment of the different costs related to flexibility.

\subsubsection{Payments from the System $\left(P_{M}\right)$ and Expected Benefit $\left(B_{N E}\right)$}

Customers pay the power system in exchange for their electricity supply. Conversely, the power system receives a service when customers participate in DR programs and must compensate them for its value.

The payment method for providing a DR service is established in the framework of an organized DR program, and the amount paid to the customer $\left(P_{M}\right)$ will be essential to determine whether the customer participates.

Customers must specify the value they require to modify their loads $\left(B_{N E}\right)$, which depends on their own market strategy. As a result of their compliance, they will reduce their loads when the net amount of money they receive $\left(B_{R}\right)$ is equal to or higher than the benefit they expect to receive, as illustrated by the equation:

$$
B_{N E} \leq B_{R}=S_{S}+P_{M}-C_{f}
$$

Consequently, the customer will only modify its load curve when the payment $\left(P_{M}\right)$ that the customer receives from the DR program operator for providing a service to the system satisfies the following condition:

$$
P_{M} \geq B_{N E}-\mathbf{Q}_{S}-C_{f}
$$

Figure 3 shows the relationship between costs and benefits with regards to customers' 
participation in DR services. The benefit obtained by the customer $\left(B_{R}\right)$ is equal to the difference between the income (benefits for consuming less expensive energy $\left(S_{S}\right)$ plus payments from the DR program operator $\left(\mathrm{P}_{\mathrm{M}}\right)$ ) and the costs that the customer incurs when a flexibility action is performed $\left(C_{f}\right) .$. As shown in the figure, the difference between the real benefit $\left(B_{R}\right)$ and the expected benefit $\left(B_{N E}\right)$ is the margin of decision $\left(M_{D}\right)$, which could be calculated as an index to verify the customer's potential participation in the DR program:

- If $M_{D}<0$, the customer will not participate in the DR program, as no benefits are obtained.

- If $M_{D} \geq 0$, the customer will provide the DR service, modifying the power load according to DR program requirements.

Customers will only participate in the DR program when expected benefits $\left(B_{N E}\right)$ are equal or higher than the obtained benefit $\left(B_{R}\right)$; in other words, when the margin of decision is positive.

\subsection{Environmental evaluation}

Avoided atmospheric emissions can be assessed in a similar way by considering the coefficients which calculate the amount of $\mathrm{CO}_{2}$ per $\mathrm{MWh}$ emitted in each time period, factors that may differ depending on the power generation mix at the time under consideration. An average value is generally used to evaluate avoided emissions at any time, and the computation consists of multiplying this factor by the amount of avoided energy [23], [24], [25]. Nevertheless, this method is not always appropriate since it does not allow emissions to be assessed when energy consumption is shifted rather than reduced. Additionally, this average could vary by countries, depending on the proportion of "clean energy" in the total generation park. Table 2 shows the emission factors for different energy sources present in the generation mix of various countries and regions.

Identifying the technology used for regulation purposes every hour is a difficult task, so the emission factor can be estimated by using an average value obtained from the generation mix. Consequently, the mean emission factor for each " $k$ " period (on-peak, shoulder and valley) can be calculated by using the following formula: 


$$
f e_{k}=\frac{E_{\text {coal }}^{k} \cdot e_{f-\text { coal }}+E_{\text {fuel-gas }}^{k} \cdot e_{f-\text { fuel-gas }}+E_{c_{-} \text {cycle }}^{k} \cdot e_{c_{-} \text {cycle }}+E_{\text {ren }}^{k} \cdot e_{\text {ren }}}{E_{\text {coal }}^{k}+E_{\text {fuel-gas }}^{k}+E_{c_{-} \text {cycle }}^{k}+E_{\text {renewable }}^{k}}\left(\operatorname{tonCO}_{2} / \mathrm{MWh}\right)(5)
$$

were $E_{\text {coal, }}^{k} E_{\text {fuel-gas }}^{k}, E_{c_{-} \text {cycle }}^{k}$ and $E_{\text {ren }}^{k}$ are the values of energy supplied by coal, fuel-gas, combined cycle and renewable technologies, respectively, during each " $k$ " period, and $e_{f}$ values are the emission factors of each energy source as specified in Table 2. To illustrate, Table 3 shows the factors used in Spain for each period of time.

The emission factor for the on-peak period is usually higher than for the rest of periods since the most inefficient technologies are supplying energy at these hours (coal and fuel-gas), and a higher amount of $\mathrm{CO}_{2}$ is emitted into the atmosphere. Therefore, if any amount of energy is shifted from the on-peak period to another period, a net reduction in emissions will be achieved. In the case of Spain, the emission factor for on-peak period is 0.750 tonCO $/ \mathrm{MWh}$.

Once the mean emission factors $\left(f_{e i}\right)$ are calculated, avoided emissions $\left(A E_{s}\right)$ during a flexibility action can be calculated by means of the following equation:

$$
A E_{s}=A E_{1}-\left(A E_{2}+A E_{3}=\sum_{k=1}^{3} E_{1}^{k} \cdot f e_{k}-\left[\sum_{k=1}^{3} E_{2}^{k} \cdot f e_{k}+\sum_{k=1}^{3} E_{3}^{k} \cdot f e_{k}\right]\left(\operatorname{tonCO}_{2}\right)\right.
$$

where $f_{e i}$ are the emissions factors for each period " $p$ ": on-peak, shoulder and valley. The method used for this environmental evaluation is presented in Figure 4.

\section{Validation of the methodology: application to the meat industry}

According to the methodology detailed above, this section assesses the economic and environmental impact of customer flexibility in the meat industry. Real data from a Spanish factory whose flexibility was previously validated [7] will be used, and the obtained results will be extrapolated to the whole segment.

The meat industry has been chosen as it is one of the most representative sectors among different industrial activities in diverse countries. It is the largest segment in U.S. agriculture [26], 
where the poultry and pork segment represents $16 \%$ of total production worldwide [27]. The share for the European Union is similar, at $18 \%$ of total global production. In the case of Spain, the production of different pork goods, such as cured ham or deli products, is well-recognized around the world [28]. Spain produces $3 \%$ of total pork worldwide. In some countries, as Canada, the most significant activity in energy terms is the meat industry, which represents $18 \%$ of total energy consumption in the national food industry. Additionally, energy use is considerable for this type of consumer, and the meat industry has been identified as one of the most suitable segments for DR implementation [19], [29].

The potential of meat industry customers to manage their loads assessed and validated in previous research [7] was attained by two different strategies:

- $1^{\text {st }}$ strategy: Interruption of cooling production and distribution in drying rooms. This strategy, demonstrated and studied in detail by the authors in [30], is based on the interruption of the electricity supply used in the refrigeration cycle so that the thermal inertia of the system can be used to keep both temperature and humidity within acceptable limits. Temperature and, consequently, the humidity ratio increases when cooling production is interrupted. Therefore, the duration of this action will depend on the stability which can be maintained in the product. Interruptions lasting up to two continuous hours can be acceptable for this type of product, as explained in [30]. Similarly, the cooling activity will be more intense during the subsequent minutes after the interruption (payback period). According to these premises, a total of two interruptions a day could be activated, so that reductions for a period of up to four hours a day could be achieved. Customers have demonstrated the ability to perform the reduction within 15 minutes of advance notice.

- $2^{\text {nd }}$ strategy: Fan speed variation in drying chambers. This action is based on the modification of the on-off sequences so that the fans work longer but at a lower speed, maintaining the total amount of water extracted from the drying chamber. Customers have frequently rejected reduction of fan speed when it has been proposed as an efficiency action since permanent reductions could stratify the air inside the chamber to the 
detriment of product quality. Consequently, this action, proposed in [7], is not the permanent modification of speed, but rather a temporary adjustment made during certain periods of time when it could be required by the TSO or advisable to avoid high market prices. The reduction of fan speed for a short period of time also reduces the total power demanded by such devices because the real power demanded by a fan is proportional to its cubed rotation speed. Hence, a large amount of energy could be saved if actions to modify this parameter are carried out

The result was decisively positive: Customers are able to achieve daily energy savings of up to $6 \%$ without compromising product quality. Likewise, for electricity operators, peak reductions of about $55 \%$ and $8 \%$ in the total load curve can be achieved after applying both strategies.

In the specific case of the studied factory, a net reduction of $711 \mathrm{~kW}$ could potentially be offered by the customer in operation markets as a result of combining the first and second strategies at the same time. Conversely, a recovery period of one hour is also needed, during which an additional amount of $114 \mathrm{~kW}$ is demanded.

\subsection{Economical evaluation of flexibility}

Customer participation in two different operation markets has been evaluated, so prices of balancing markets and the secondary regulation market have been considered for the mobile year between November 25, 2009 and November 25, 2010. Prices were obtained from the official REE website, where this information is published and updated daily.

\subsubsection{Balancing markets simulation}

Prices of balancing markets varied in the considered period from $5 €$ to $210 € / \mathrm{MWh}$, as shown in Figure 5.

According to the method proposed in section 3, a total of 670 hours, whose daily assignment is shown in Figure 6, were considered acceptable in the simulation, since the customer could obtain at least the minimum required benefit.

If the customer had participated in this market for all the considered hours, it would have 
obtained a benefit up to $45,271 €$, or $6.2 \%$ of the total cost of electricity. $32,588 €$ comes from energy not consumed by the customer (savings), including the different costs that the customer incurs, and $12,683 €$ are direct payments from the TSO. The actual cost that this reduction of power had for the system by using generation resources was $21,639 €$. Consequently, the system would have saved $8,956 €$ if $\mathrm{DR}$ from this customer had been used instead of only generation resources. Figure 7 shows the monthly result of this customer's participation in the balancing market. The most profitable month for customer participation, from both the customer and system perspective, was November, when the customer would have earned $7,365 €$ while the system would have saved $1,243 €$.

\subsubsection{Secondary regulation simulation}

The participation of the customer in the Spanish secondary regulation market was also evaluated, similarly to the analysis performed on the balancing market. The secondary regulation market has two components, since customers are paid for availability (reserves) as well as for actual delivery of the power. Figures 8 and Figure 9 show the prices for availability and delivered energy in the Spanish secondary regulation market, from November 25, 2009 to November 25, 2010.

The customer would obtain a minimum required benefit for a total of 450 hours, whose daily assignment is shown in Figure 10.

Participating in the secondary reserve for all the hours under consideration, the customer would have obtained a benefit of $6,594 €$, equivalent to $0.9 \%$ of the total cost of electricity. At the same time, the system would have saved $9,263 €$ by using the customer's capacity instead of conventional generation.

In addition to the benefit obtained by the customer for its availability, an additional payment of $7,781 €$ would have been obtained if the power was delivered during the pledged hours. This can be added to the savings achieved by avoiding consumption, which reach $17,408 €$ after discounting costs. Therefore, a total benefit of $31,783 €$ could be obtained by the customer, which is $4.4 \%$ of the total cost of electricity.

Figure 11 shows the monthly results of this customer's participation in the secondary regulation

(availability + delivery) market. The most profitable month for customer participation, for both the 
customer and the system, was January, when the customer would have earned $7,256 €$, and the system would have saved $2,005 €$.

\subsubsection{Sensitivity analysis}

In order to evaluate how variations in some of the parameters considered in the simulation affect to the final result of the proposed methodology, a sensitivity analysis has been performed as it is explained in the following paragraphs.

As real prices for balancing and secondary regulation markets were used for the considered period of time, variations in the benefit strategy considered in step 3 of section 3.1 have been evaluated. While an initial value of $50 \%$ of the cost of the offered amount of power (strategy $50 \%$ ), according to the price in the electricity contract of the customer, was considered as an acceptable strategy in the simulation, variations in a range between $0 \%$ (that means no additional payments from the TSO) and $100 \%$ has been also simulated so as to identify how such variables as the number of hours in that the customer would participate or the avoided costs for the system are affected.

The obtained results for the case of balancing markets are presented in Table 4. When the benefit required by the customer to be willing to modify its loads increases, the number of hours of participation is gradually reduced. However, this reduction is not directly related to the total benefit obtained by the customer: when the required benefit varies between $0 \%$ and $25 \%$ over the cost of the offered amount of power, a reduction of the number of hours of participation does not imply a reduction in the benefit, as the total benefit for the customer increases. Nevertheless, the benefit is reduced for percentages higher than $25 \%$ as the loss of benefits due to the reduction of hours in that the customer may participate is higher than the specific increment of benefit in each hour. The benefit is drastically reduced for required benefits higher than $60 \%$.

Likewise, Table 5 includes a similar evaluation for the secondary regulation. In this case, the range of hours in that the customer may participate is wider as it varies between 1460 and 166 hours, depending on the required benefit.

According to these results, it can be concluded that the considered value of $50 \%$ is adequate to allow customers to obtain significant benefits with a reasonable number of energy reductions a year 
although, as mentioned in section 3.1 .3 , this decision will depend on the market strategy of each particular customer.

\subsubsection{Extrapolation of results to the whole segment}

The potential for customers in the whole segment of the meat products industry has been estimated by using tools developed in the project carried out by the International Energy Agency (IEA), task XIII "Demand Response Resources" [20], of the Implementing Agreement on Demand Side Management. These tools estimate the available market potential for DR in electricity markets. For the calculation, benchmark information gathered from experiences with consumers in Europe and America is used. Table 6 shows the inputs considered in order to estimate the potential of DR in the meat industry in Spain, which has been estimated at $441 \mathrm{MW}$. According to these results, it is possible to conclude that the meat products segment has a high potential to provide DR resources to the system, with very profitable results. During the considered period (from November 25, 2009 to November 25, 2010), about 2011 GWh were managed in balancing markets in Spain, with a cost of 85,534 thousands of $€^{1}$. Taking into account the potential estimated above, $14.7 \%$ of this energy could have been reduced by customers from the meat producing segment. This would have avoided system costs of approximately 5,557 thousands of $€$, or $6.5 \%$ of the total cost of balancing markets for the system in this period.

Similarly, the cost of the secondary reserve up for the considered period was 92,836 thousands of $€^{1}$. The estimated avoided cost for the system, considering the potential of the whole segment, is 5,731 thousands of $€$. Thus, the system could save about $6.2 \%$ of the total cost of secondary regulation if DR from this segment were used.

\subsection{Environmental impact of flexibility}

As stated in section 3.2, the assessment of avoided emissions into the atmosphere could be performed by considering the weighted coefficients which assess the amount of $\mathrm{CO}_{2}$ per $\mathrm{MWh}$ emitted in each time period. Below, the avoided emissions into the atmosphere are assessed for the customer analyzed in this paper. The procedure that was used is the following:

\footnotetext{
${ }^{1}$ This information has been obtained from the Spanish TSO. http://www.esios.ree.es
} 
- First of all, the total emissions by the customer when no reductions are produced are evaluated by assessing the consumption of energy in each one of the six periods defined in the contract. For that purpose, the emission coefficients stated in Table 7 are considered, and the emission of each period is calculated by multiplying the consumption of each period by the assigned factor.

- Secondly, emissions are calculated after implementing the flexibility strategies dealt with in the section, including the extra consumption produced during the recovery period of the first strategy.

- Finally, the avoided emissions into the atmosphere are calculated as the difference between the results obtained in steps 1 and 2 .

Results of the total amount of $\mathrm{CO}_{2}$ emitted into the atmosphere before and after reducing energy in both balancing markets and secondary regulation are presented in Table 8, achieving savings up to the $3 \%$ and $5 \%$ in balancing markets and secondary regulation, respectively.

\section{Conclusions}

This paper presents a methodology, which is applied to customers from the meat products industry, to assess the economic impact of customers participating in operation markets, as well as the amount of avoided $\mathrm{CO}_{2}$ into the atmosphere. The participation of a typical customer that produces meat products, whose technical potential was analyzed in previous research, has been simulated in the framework of operation markets such as the balancing markets and secondary regulation in Spain, where tests in real customers were performed. As a result, this methodology demonstrates a high potential of customers from this segment to provide the system with DR services in a profitable way for both the customer and the power system as a whole.

When the case of balancing markets was analyzed, savings of $6.2 \%$ in the annual electricity bill of the customer were obtained by applying flexibility strategies. If this potential is used for secondary regulation, savings of almost the $5 \%$ in the annual bill could be achieved.

The avoided cost arising from DR participation in these operation markets has also been 
evaluated, as the difference between the payment required by the customer and the cost of this service when it is provided by only generation resources. After estimating the potential of the whole segment by using tools developed in the Task XIII of the IEA, savings exceeded $6 \%$ for the whole power system. These results demonstrate the high potential in this segment, as individual customers can obtain appreciable benefits while also contributing to significant reductions in the total cost of power system management.

\section{Acknowledgment}

The authors gratefully acknowledge the contributions of Campofrío Food Group, S.A.

\section{References}

[1] Pérez Arriaga JL. Libro Blanco sobre la reforma del marco regulatorio de la generación eléctrica en España. Ministerio de Industria, Turismo y Comercio. Madrid, June 2005

[2] Greening LA. Demand response resources: who is responsible for implementation in a deregulated market?. Energy 2011; 35; 1518-1525.

[3] Álvarez-Bel C, Gabaldón-Marín A, Valencia-Salazar I, Alcázar-Ortega M, Escrivá-Escrivá G. Market Integration of Responsive Customers: Application to Energy and Balancing Markets. International Journal of Power and Energy Systems Design 2009; 29; 48-56.

[4] Tractebel Engineering Suez. Study on interaction and dependencies of balancing markets, intraday trade and automatically activated reserves. Suez-Tractebel, S.A., final report, February 2009. Available online: http://www.tractebel-engineering.com

[5] Raineri R, Ríos S, Schiele D. Technical and economic aspects of ancillary services markets in the electric power industry: and international comparison. Energy Policy 2006; 34; 15401555.

[6] Al-Sunaidy A, Green R. Electricity deregulation in OECD (Organization for Economic Cooperation and Development) countries. Energy 2006; 31; 769-787 
[7] Alcázar-Ortega M, Álvarez-Bel C, Domijan A, Escrivá-Escrivá G. Active demand response strategies to improve energy efficiency in the meat industry. World Renewable Energy Congress 2011. May 8th-13th 2011. Linköping (Sweden)

[8] Escrivá-Escrivá G, Segura-Heras I, Alcázar-Ortega M. Application of an energy management and control system to assess the potential of different control strategies in HVAC systems. Energy and Buildings 2010; 42; 2258-2267.

[9] Escrivá G, Alcázar-Ortega M, Álvarez C. Integral Management System for the energy efficiency improvement in commercial facilities: Application to the Polytechnic University of Valencia. International Conference on Renewable Energies and Power Quality 2009. April 15th - 17th. Valencia (Spain)

[10] Bourgain G (coord.) et al. Integrating distributed energy resources into today's electrical system. ExpandDER, June 2009.

[11] Kim JH, Shcherbakova A. Common failures of demand response. Energy 2011; 36; 873-880

[12] Foley AM, Ó Gallachóir BP, Hur J, Baldick R, McKeogh EJ. A strategic review of electricity systems models. Energy 2010; 35; 4522-4530

[13] Moritz Paulus M, Borggrefe F. The potential of demand-side management in energyintensive industries for electricity markets in Germany. Applied Energy 2011; 88; 432-441.

[14] Centolella P. The integration of Price Responsive Demand into Regional Transmission Organization (RTO) wholesale power markets and system operations. Energy 2010; 35; 1568-1574.

[15] Goel L, Wu Q, Wang P. Reliability enhancement of a deregulated power system considering demand response. IEEE Power Engineering Society General Meeting 2006, doi: 10.1109/PES.2006.1708965. Montreal (Canada)

[16] Walawalkar R, Fernands S, Thakur N, Chevva K. Evolution and current status of demand response (DR) in electricity markets: Insights from PJM and NYISO. Energy 2010; 35; 15531560.

[17] Comisión Nacional de la Energía (CNE). Annual Report 2007. Available online on http://www.cne.es 
[18] Álvarez-Bel C, Alcázar-Ortega M, Escrivá-Escrivá G, Gabaldón-Marín A. Technical and economical tools to assess customer demand response in the commercial sector. Energy Conversion and Management 2009; 50; 2605-2612.

[19] The birth of a EUropean Distributed EnErgy Energy Partnership that will help the large-scale implementation of distributed energy resources in Europe (EU-DEEP), the European Project supported by the Sixth Framework programme for Research and Technological Development. Available online: http://www.eu-deep.com

[20] International Energy Agency (IEA) Demand Response Resources - Task XIII. Available online: http://demandresponseresources.com

[21] Red Eléctrica de España, S.A. Emisiones de $\mathrm{CO}_{2}$ producidas en el sistema eléctrico en tiempo real. REE, S.A., June 2009

[22] AICIA: "Condiciones de aceptación de procedimientos alternativos a LIDER y CALENER". Instituto para la Diversificación y Ahorro de la Energía (IDAE) y Ministerio de la Vivienda. Madrid, May 2009

[23] Psomopoulosa CS, Skoulab I, Karrasc C, Chatzimpirosb A, Chionidisb M. Electricity savings and $\mathrm{CO} 2$ emissions reduction in buildings sector: How important the network losses are in the calculation?. Energy 2010; 35; 485-490.

[24] Siitonena S, Tuomaalaa M, Suominenb M, Ahtilaa P. Implications of process energy efficiency improvements for primary energy consumption and $\mathrm{CO} 2$ emissions at the national level. Applied Energy 2010; 87; 2928-2937.

[25] Malla S. $\mathrm{CO}_{2}$ emissions from electricity generation in seven Asia-Pacific and North American countries: A decomposition analysis. Energy Policy 2009; 37; 1-9.

[26] The United States Meat Industry. American Meat Institute AMI. March 2009 Report. Available online: http://www.meatami.com

[27] FAOSTAT. Food and Agriculture Organization of the United Nations. Annual Statistical Report, 2005. Available online: http://faostat.fao.org, accessed on February 2009.

[28] Norup J. Improving Industrial Energy Efficiency in the food industry. 2007 Growing the Margins Energy Conference. London (ON, Canada) April, 12th-13th 2007. Available online: http://www.gtmconference.ca 
[29] Alfonso D, Pérez-Navarro A, Encina N, Álvarez C, Rodríguez J, Alcázar-Ortega M. Methodology for ranking of customer segments by their suitability for distributed energy resources applications. Energy Conversion and Management 2007; 48; 1615-1623.

[30] Alcázar-Ortega M, Álvarez-Bel C, Escrivá-Escrivá G, Domijan A. Evaluation and assessment of demand response potential applied to the meat industry. Applied Energy 2012; 92; 84-91. 


\section{Figure captions}

Figure 1. Participation of customers in electricity markets in the MIBEL

Figure 2. Proposed methodology for the economic evaluation

Figure 3. Economic evaluation of flexibility: cost-benefit analysis for customers

Figure 4. Proposed methodology for the environmental evaluation

Figure 5. Prices in the Spanish balancing market from November ' 09 to November '10

Figure 6. Participation hours in balancing markets

Figure 7. Monthly results of the customer participation in the Spanish balancing market

Figure 8. Prices in the Spanish secondary regulation market (availability) from November '09 to November ' 10

Figure 9. Prices in the Spanish secondary regulation market (delivery) from November '09 to November ' 10

Figure 10. Participation hours in secondary regulation market

Figure 11. Monthly results of the customer participation in the Spanish secondary regulation market

\section{$\underline{\text { Table captions }}$}

Table 1. Definition of periods in seasonality contracts in Spain

Table 2. Emission factors for different sources of energy and countries

Table 3. Emission factors for different periods in Spain

Table 4. Sensitivity analysis: strategy evaluation in balancing markets

Table 5. Sensitivity analysis: strategy evaluation in secondary regulation

Table 6. Inputs for the IEA task XIII tool - Segment of Meat Products 
Table 7. Emission factors for a 6 period contract in Spain

Table 8. Avoided emission into the atmosphere for one customer 
Bilateral contracts $35 \%$
SPOT

$59 \%$

Organized markets $65 \%$

\section{$6 \%$}

Forward 


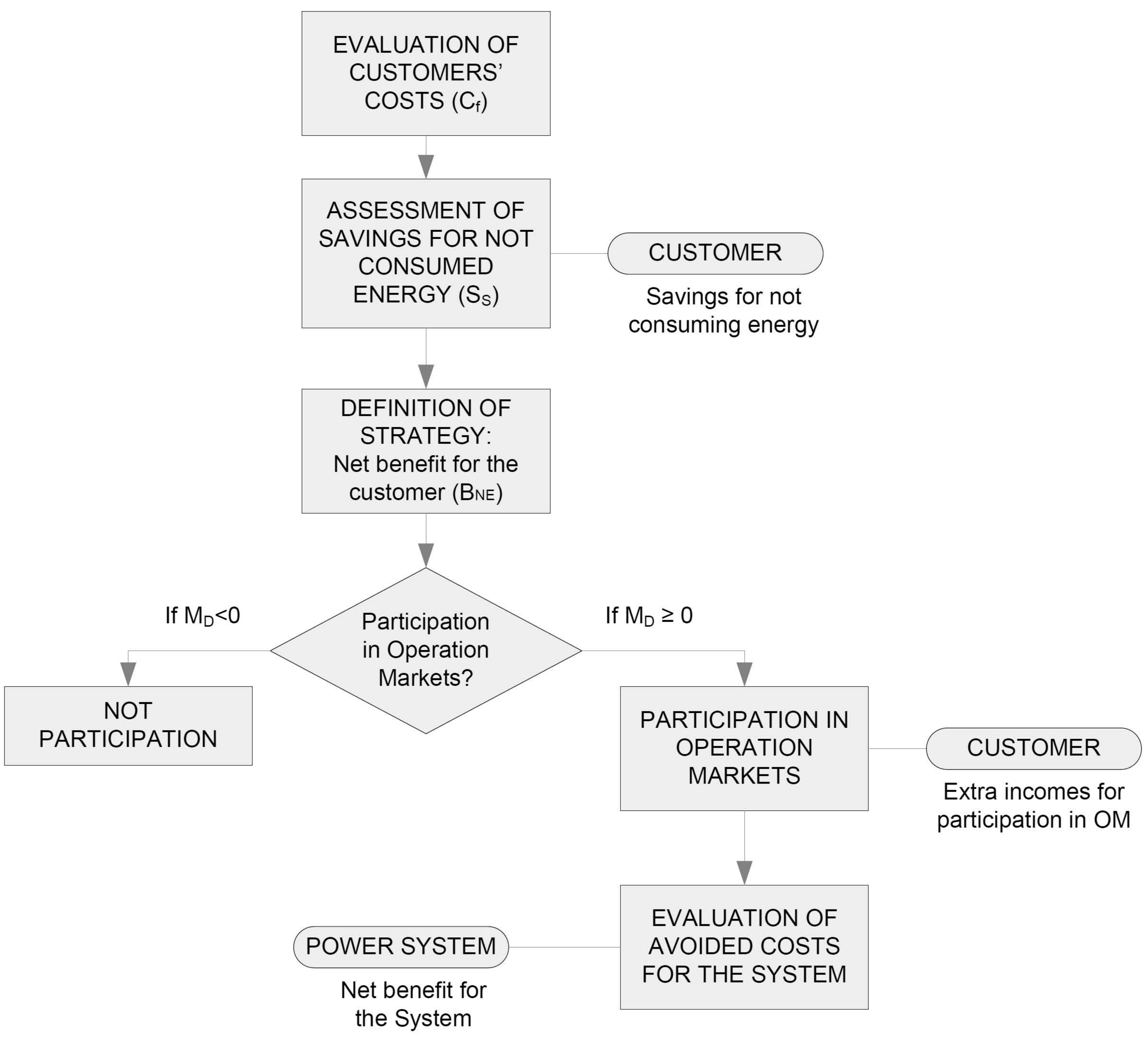


$\mathrm{S}_{\mathrm{S}}$

$P_{M}$

INCOME

EXPENSES

$\mathrm{C}_{\mathrm{f}}$

REAL BENEFIT

EXPECTED BENEFIT

MARGIN OF DECISION

$B_{R}$

\section{$\mathrm{B}_{\mathrm{NE}}$}

$M_{D}=B_{R}-B_{N E}$ 


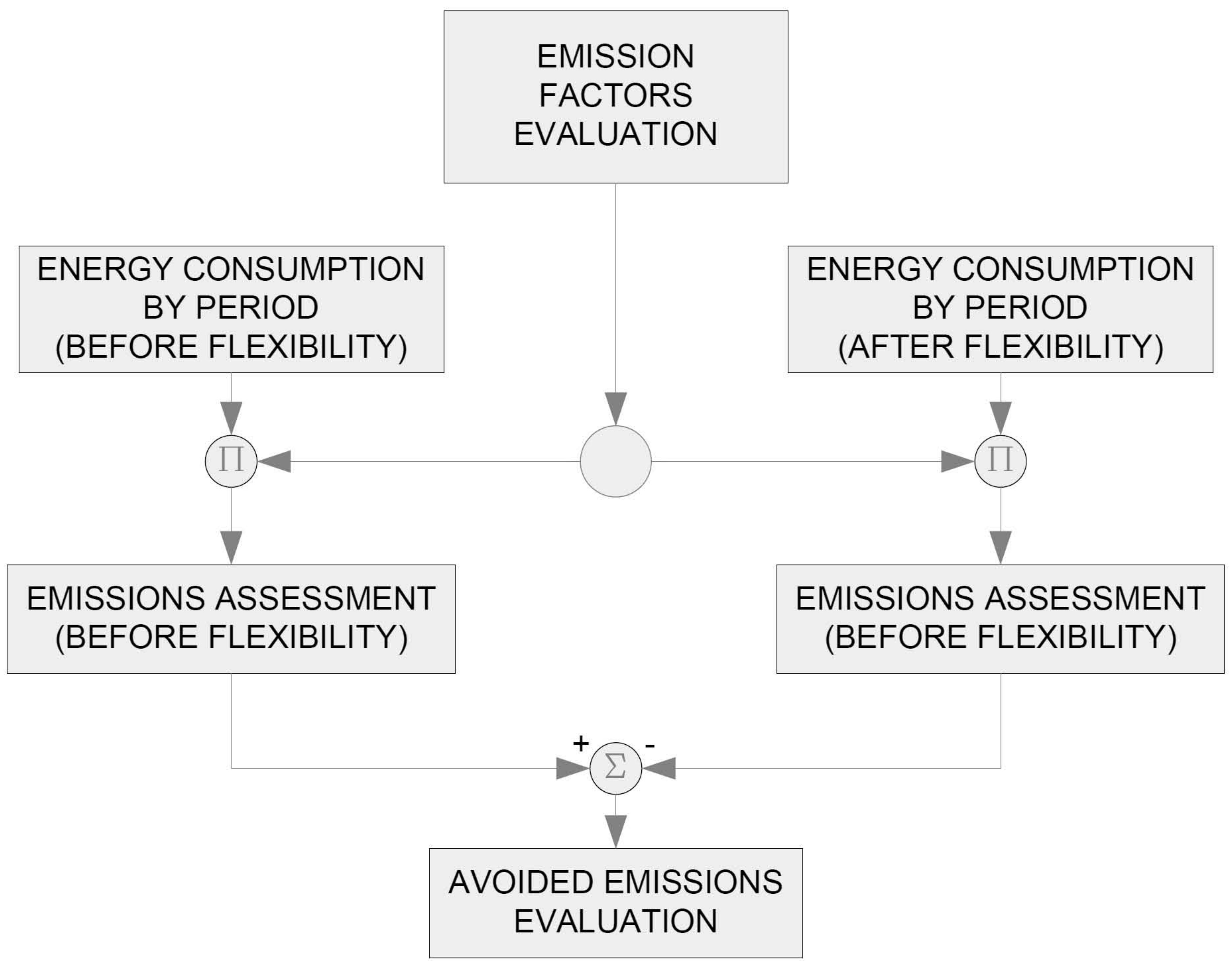




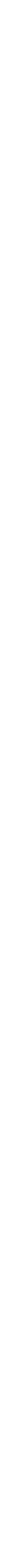




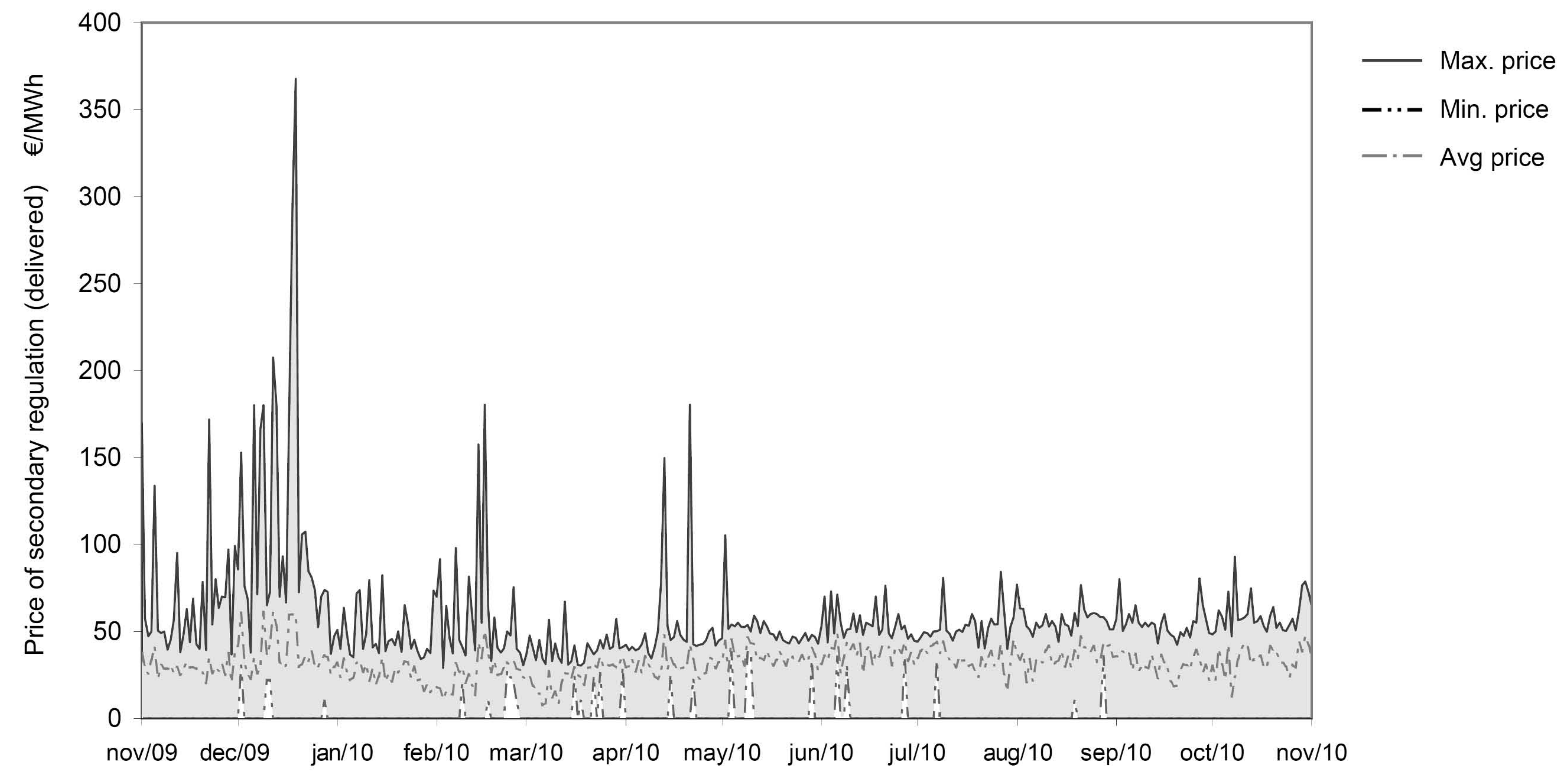




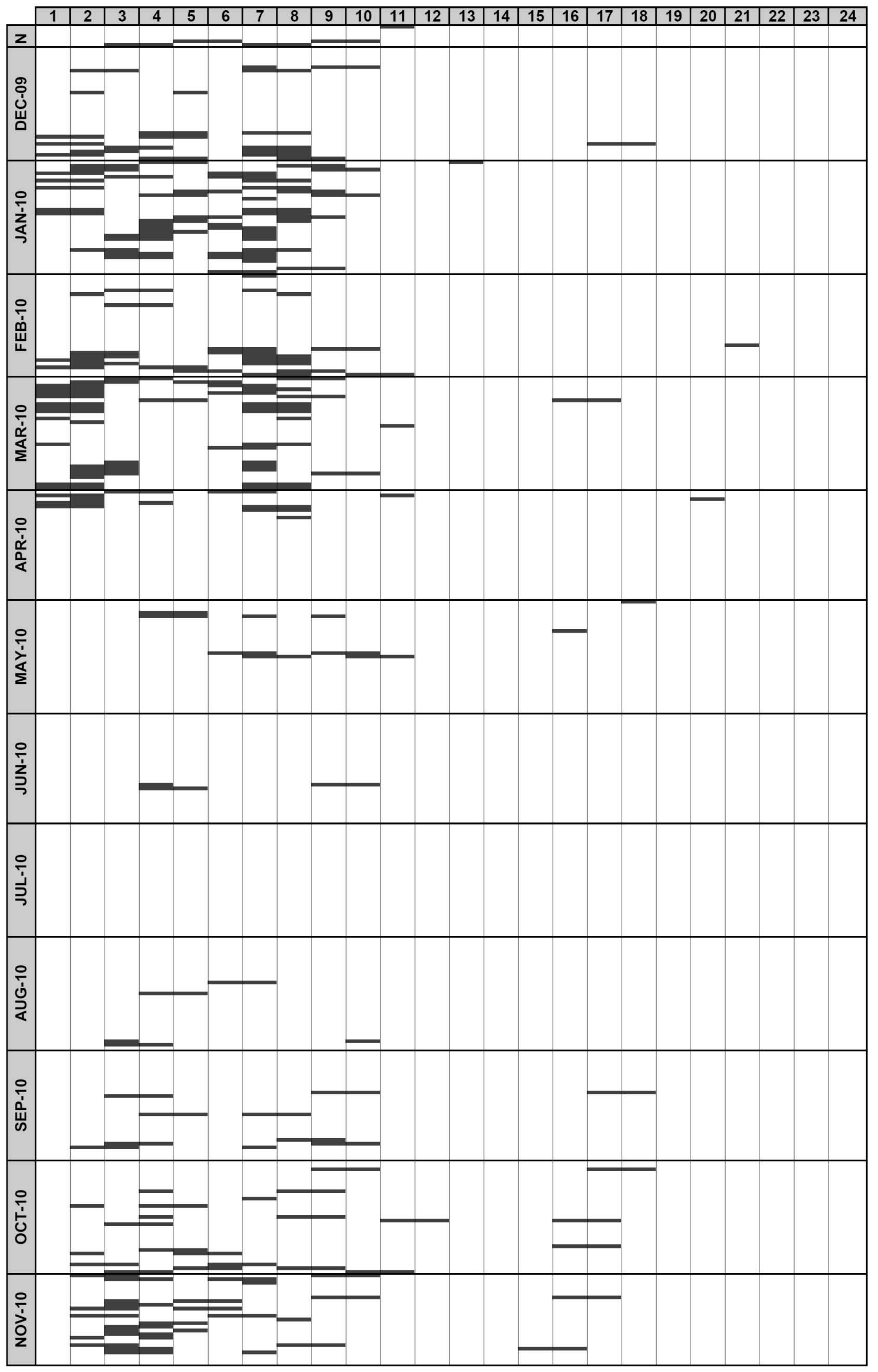







Table 1. Definition of periods in seasonality contracts in Spain.

Source: Spanish Act ITC 2794/2007

\begin{tabular}{|c|c|c|c|c|c|c|c|c|}
\hline & & & \\
\hline & & & $\begin{array}{l}\text { January, } \\
\text { February } \\
\text { and } \\
\text { December }\end{array}$ & $\begin{array}{l}2^{\text {nd }} \text { half of } \\
\text { June and } \\
\text { July }\end{array}$ & $\begin{array}{l}\text { March and } \\
\text { November }\end{array}$ & $\begin{array}{l}1^{\text {st }} \text { half of } \\
\text { June and } \\
\text { September }\end{array}$ & $\begin{array}{c}\text { April, May } \\
\text { and } \\
\text { October }\end{array}$ & August \\
\hline \multirow{8}{*}{ 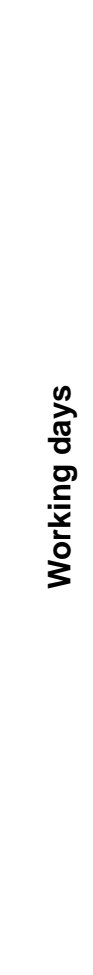 } & \multirow{3}{*}{ 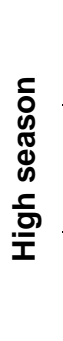 } & $\begin{array}{l}\text { On-peak } \\
\text { (P1) }\end{array}$ & $\begin{array}{l}10 \mathrm{am}-1 \mathrm{pm} \\
6 \mathrm{pm}-9 \mathrm{pm}\end{array}$ & $11 \mathrm{am}-7 \mathrm{pm}$ & - & - & - & - \\
\hline & & $\begin{array}{l}\text { Shoulder } \\
\text { (P2) }\end{array}$ & $\begin{array}{c}\text { 8am-10am } \\
\text { 1pm-6pm } \\
9 p m-12 a m\end{array}$ & $\begin{array}{l}8 \mathrm{am}-11 \mathrm{am} \\
7 \mathrm{pm}-12 \mathrm{am}\end{array}$ & - & - & - & - \\
\hline & & $\begin{array}{c}\text { Valley } \\
\text { (P6) }\end{array}$ & $12 \mathrm{am}-8 \mathrm{am}$ & 12am-8am & - & - & - & - \\
\hline & \multirow{3}{*}{ 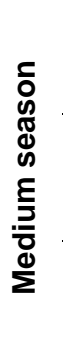 } & $\begin{array}{l}\text { On-peak } \\
\text { (P3) }\end{array}$ & - & - & 4pm-10pm & $9 a m-3 p m$ & - & - \\
\hline & & $\begin{array}{l}\text { Shoulder } \\
\text { (P4) }\end{array}$ & - & - & $\begin{array}{c}\text { 8am-4pm } \\
10 p m-12 a m\end{array}$ & $\begin{array}{l}\text { 8am-9am } \\
\text { 3pm-12am }\end{array}$ & - & - \\
\hline & & $\begin{array}{c}\text { Valley } \\
\text { (P6) }\end{array}$ & - & - & 12am-8am & 12am-8am & - & - \\
\hline & \multirow{2}{*}{ 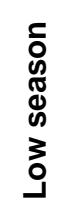 } & $\begin{array}{l}\text { Shoulder } \\
\text { (P5) }\end{array}$ & - & - & - & - & $8 a m-12 a m$ & - \\
\hline & & $\begin{array}{l}\text { Valley } \\
(\mathrm{P} 6)\end{array}$ & - & - & - & - & 12am-8am & - \\
\hline \multicolumn{2}{|c|}{$\begin{array}{l}\text { Non-working } \\
\text { days }\end{array}$} & $\begin{array}{c}\text { Valley } \\
\text { (P6) }\end{array}$ & $\begin{array}{l}24 \text { hours } \\
\text { a day }\end{array}$ & $\begin{array}{l}24 \text { hours } \\
\text { a day }\end{array}$ & $\begin{array}{l}24 \text { hours } \\
\text { a day }\end{array}$ & $\begin{array}{c}24 \text { hours } \\
\text { a day }\end{array}$ & $\begin{array}{l}24 \text { hours } \\
\text { a day }\end{array}$ & $\begin{array}{c}24 \text { hours } \\
\text { a day }\end{array}$ \\
\hline
\end{tabular}


Table 2. Emission factors for different sources of energy and countries

Source: Red Eléctrica de España [21] for Spain and the World Nuclear Association (http://www.world-nuclear.org) for the rest of countries. According to this last reference, emissions assigned to solar photovoltaic, wind power, nuclear and hydraulic are due to indirect causes from life cycle.

\begin{tabular}{ccccccc}
\hline $\begin{array}{c}\text { Emissions } \\
\text { tonCO } / \text { MWh }\end{array}$ & Spain & Sweden & Finland & UK & Japan & $\begin{array}{c}\text { EU } \\
\text { External }\end{array}$ \\
\hline $\begin{array}{c}\text { Coal } \\
\text { Fuel - gas }\end{array}$ & 0.95 & 0.98 & 0.89 & 0.89 & 0.99 & 0.82 \\
Gas combined cycle & 0.70 & 1.17 & - & - & 0.65 & - \\
Solar photovoltaic & 0.00 & 0.45 & 0.47 & 0.36 & - & 0.36 \\
Wind Power & 0.00 & 0.01 & 0.10 & - & 0.06 & 0.05 \\
Nuclear & 0.00 & 0.01 & - & 0.02 & 0.02 & 0.01 \\
Hydraulic & 0.00 & 0.00 & - & - & 0.02 & - \\
Rest of renewable & 0.25 & - & - & - & - & - \\
\hline
\end{tabular}


Table 3. Emission factors for different periods in Spain Source: Spanish Departments of Industry and Housing [22]

\begin{tabular}{lc}
\hline \multicolumn{1}{c}{ Period } & $\begin{array}{c}\text { Emission factor } \boldsymbol{f e}_{\mathrm{k}} \\
\left(\mathrm{tCO}_{2} / \mathbf{M W h}\right)\end{array}$ \\
\hline On peak and shoulder & 0.649 \\
Valley & 0.517 \\
\hline
\end{tabular}


Table 4. Sensitivity analysis: strategy evaluation in balancing markets

\begin{tabular}{rcrrr}
\hline Strategy & $\begin{array}{c}\text { Hours/year } \\
\text { of } \\
\text { interruption }\end{array}$ & \multicolumn{2}{c}{$\begin{array}{c}\text { Benefit for the customer } \\
\text { €/year }\end{array}$} & $\begin{array}{c}\text { Avoided costs } \\
\text { for the system } \\
\text { of electricity }\end{array}$ \\
\hline $0 \%$ & 745 & 44.451 & $6.1 \%$ & 24,289 \\
$5 \%$ & 745 & 46.274 & $6.3 \%$ & 22,456 \\
$10 \%$ & 745 & 48.096 & $6.6 \%$ & 20,623 \\
$15 \%$ & 741 & 49.650 & $6.8 \%$ & 18,793 \\
$20 \%$ & 737 & 51.137 & $7.0 \%$ & 16,973 \\
$25 \%$ & 736 & 52.671 & $7.2 \%$ & 15,177 \\
$30 \%$ & 726 & 52.481 & $7.2 \%$ & 13,584 \\
$35 \%$ & 715 & 51.076 & $7.0 \%$ & 12,288 \\
$40 \%$ & 705 & 48.479 & $6.6 \%$ & 11,306 \\
$45 \%$ & 688 & 46.313 & $6.3 \%$ & 10,178 \\
$50 \%$ & 670 & 45.271 & $6.2 \%$ & 8,956 \\
$55 \%$ & 670 & 45.784 & $6.3 \%$ & 7,805 \\
$60 \%$ & 664 & 45.684 & $6.3 \%$ & 6,702 \\
$65 \%$ & 614 & 43.022 & $5.9 \%$ & 5,600 \\
$70 \%$ & 561 & 39.751 & $5.4 \%$ & 4,692 \\
$75 \%$ & 494 & 35.265 & $4.8 \%$ & 3,867 \\
$80 \%$ & 427 & 30.896 & $4.2 \%$ & 3,123 \\
$85 \%$ & 338 & 25.046 & $3.4 \%$ & 2,465 \\
$90 \%$ & 255 & 19.271 & $2.6 \%$ & 1,955 \\
$95 \%$ & 192 & 14.802 & $2.0 \%$ & 1,582 \\
$100 \%$ & 139 & 10.975 & $1.5 \%$ & 1,302 \\
\hline & & & &
\end{tabular}


Table 5. Sensitivity analysis: strategy evaluation in secondary regulation

\begin{tabular}{|c|c|c|c|c|}
\hline \multirow{2}{*}{ Strategy } & \multirow{2}{*}{$\begin{array}{l}\text { Hours/year } \\
\text { of } \\
\text { interruption }\end{array}$} & \multicolumn{2}{|c|}{ Benefit for the customer } & \multirow{2}{*}{$\begin{array}{c}\text { Avoided costs } \\
\text { for the system } \\
€ / \text { year }\end{array}$} \\
\hline & & $€ /$ year & $\begin{array}{l}\% \text { in total cost } \\
\text { of electricity }\end{array}$ & \\
\hline $0 \%$ & 1,460 & 89.449 & $12.2 \%$ & 24,922 \\
\hline $5 \%$ & 1,454 & 91.907 & $12.6 \%$ & 22,285 \\
\hline $10 \%$ & 1,446 & 89.867 & $12.3 \%$ & 19,953 \\
\hline $15 \%$ & 1,400 & 86.222 & $11.8 \%$ & 17,780 \\
\hline $20 \%$ & 1,166 & 72.741 & $9.9 \%$ & 15,786 \\
\hline $25 \%$ & 946 & 60.275 & $8.2 \%$ & 14,186 \\
\hline $30 \%$ & 805 & 52.396 & $7.2 \%$ & 12,830 \\
\hline $35 \%$ & 660 & 43.991 & $6.0 \%$ & 11,705 \\
\hline $40 \%$ & 585 & 39.967 & $5.5 \%$ & 10,774 \\
\hline $45 \%$ & 498 & 34.700 & $4.7 \%$ & 9,960 \\
\hline $50 \%$ & 450 & 31.783 & $4.3 \%$ & 9,236 \\
\hline $55 \%$ & 401 & 29.257 & $4.0 \%$ & 8,593 \\
\hline $60 \%$ & 371 & 27.563 & $3.8 \%$ & 7,989 \\
\hline $65 \%$ & 330 & 24.955 & $3.4 \%$ & 7,477 \\
\hline $70 \%$ & 296 & 22.754 & $3.1 \%$ & 6,989 \\
\hline $75 \%$ & 268 & 21.033 & $2.9 \%$ & 6,543 \\
\hline $80 \%$ & 245 & 19.562 & $2.7 \%$ & 6,160 \\
\hline $85 \%$ & 216 & 17.811 & $2.4 \%$ & 5,858 \\
\hline $90 \%$ & 200 & 16.803 & $2.3 \%$ & 5,552 \\
\hline $95 \%$ & 189 & 16.196 & $2.2 \%$ & 5,260 \\
\hline $100 \%$ & 166 & 14.471 & $2.0 \%$ & 4,991 \\
\hline
\end{tabular}


Table 6. Inputs for the IEA task XIII tool - Segment of Meat Products

\begin{tabular}{lrll}
\cline { 1 - 2 } Number of meat products factories in Spain & 4,505 & & $\begin{array}{l}\text { Source: } \text { Asociación de Industrias } \\
\text { de la Carne de España }\end{array}$ \\
\cline { 1 - 2 } Peak power in Spain, MW & 43,378 & & $\begin{array}{l}\text { Source: } R E E \\
\text { Seurce: tests in real factories }\end{array}$ \\
\cline { 1 - 2 } Peak power for a typical factory, MW & 0.964 & & Source: tests in real factories \\
\cline { 1 - 2 } Avg. reducible power for a typical factory, MW & 0.710 & & Task XIII tool
\end{tabular}


Table 7. Emission factors for a six-period contract in Spain

\begin{tabular}{clc}
\hline Period & \multicolumn{1}{c}{ Definition } & $\begin{array}{c}\text { Coefficient } \\
\text { tonCO }\end{array} / \mathrm{MWh}$ \\
\hline P1 & On-peak in high season & 0.750 \\
P2 & Shoulder in high season & 0.649 \\
P3 & On-peak in medium season & 0.750 \\
P4 & Shoulder in medium season & 0.649 \\
P5 & Shoulder in low season & 0.649 \\
P6 & Valley & 0.517 \\
\hline
\end{tabular}


Table 8. Avoided emission into the atmosphere for one customer

\begin{tabular}{|c|c|c|c|c|c|}
\hline \multirow[b]{2}{*}{ Period } & \multirow{2}{*}{$\begin{array}{c}\text { Initial } \\
\text { Emissions } \\
\text { Ton } \mathrm{CO}_{2} / \text { year }\end{array}$} & \multicolumn{2}{|c|}{ Balancing Markets } & \multicolumn{2}{|c|}{ Secondary Regulation } \\
\hline & & $\begin{array}{c}\text { Final } \\
\text { Ton } \mathrm{CO}_{2} / \text { year }\end{array}$ & $\begin{array}{c}\text { Savings } \\
\text { Ton } \mathrm{CO}_{2} / \text { year }\end{array}$ & $\begin{array}{c}\text { Final } \\
\text { Ton } \mathrm{CO}_{2} / \text { year }\end{array}$ & $\begin{array}{c}\text { Savings } \\
\text { Ton } \mathrm{CO}_{2} / \text { year }\end{array}$ \\
\hline P1 & 452.9 & 449.9 & 2.9 & 452.9 & - \\
\hline $\mathbf{P 2}$ & 542.1 & 534.9 & 7.2 & 541.7 & 0.4 \\
\hline P3 & 327.8 & 319.4 & 8.3 & 327.8 & - \\
\hline P4 & 473.4 & 445.0 & 28.4 & 472.6 & 0.8 \\
\hline P5 & 619.4 & 608.4 & 11.0 & 619.0 & 0.4 \\
\hline P6 & $2,447.0$ & $2,265.5$ & 181.4 & $2,315.5$ & 131.4 \\
\hline TOTAL & $4,862.5$ & $4,623.2$ & 239.4 & $4,729.4$ & 133.1 \\
\hline
\end{tabular}

